\title{
Development of Adequate Library Resources in Rural Communities
}

T's A vicious circle," remarked Charles H. Brown, librarian of Iowa State College, after a visit to some rural schools back in the 1920's. He was referring to the handicaps placed upon children, parents, teachers, and others in rural communities by the lack of public and school library facilities; to the failure of many colleges to inspire students with a true appreciation of the value of books and reading; and to the unconcern of many of these students, as teachers and leaders later in farm areas, about the essentiality of adequate library facilities. As Charles H. Brown has had a deep interest in many angles of the rural library problem, it seems appropriate to review some aspects of it.

\section{Statistics of the Problem}

The first facts which loom up are statistical ones. Of our $57,000,000$ persons who live in places with populations under 2500 or on farms, $32,000,000$ have no public libraries within reach. In terms of space instead of persons, it has been estimated that about two-thirds of the total area of continental United States is without public library facilities. ${ }^{1}$ The situation for rural school libraries appears equally dismal, although complete figures are not available. According to data gathered in 1942 by the U.S. Office of Education, ${ }^{2} 8206$ rural

1 Joeckel, Carleton B. "Library Extension Today." In University of Chicago. Graduate Library School. Library Institute. Library Extension: Problems and Solutions. Chicago, University of Chicago Press, 1945, p. ${ }_{2} 8$.
.S. Office of Education. Statistics of Public schools had no library facilities whatever, 28,853 had only service of an unspecified nature (which probably means highly inadequate service), and 90,000 did not reply (many of which may be assumed to have little or no service). In other words, a conservative estimate would place 60 per cent of the rural schools with little or no library service.

The complicating factors of population density and per capita ability to support rural library service are well-known. For example, New Mexico with only four and a fraction persons per square mile presents quite a different problem for library extension workers than does Massachusetts which has 545.9 persons per square mile. In the matter of income payments to individuals, the 1944 per capita amounts in Mississippi and Arkansas were $\$ 528$ and $\$ 6$ or respectively, whereas the comparative figure for New York was \$1519; for Connecticut, $\$ 1509$; and for California, \$1480. Then there is the oft-quoted statement that farm children constitute $3 \mathrm{I}$ per cent of the nation's children of school age, but farm income is only 9 per cent of the total national income.

\section{Points of Attack}

The attack on the problem of extending rural library service involves action on many fronts: (I) strengthening the state library

School Libraries, $-194 I-42$ by Nora E. Beust and Edith M. Foster. Biennial Surveys of Education, $1938-40$ and 1940-42, vol. 2, chap. 8 , p. 9 . 
agencies, (2) recruiting personnel fitted for work in rural areas, (3) determining the proper size and type of local library units, (4) obtaining financial support, (5) fostering cooperative efforts on the part of all types of libraries.

At the present time forty-seven states have state library agencies, the primary function of which is to extend and improve public and school library service. In nineteen states there is now a library specialist to provide service at the state level to school libraries. These state agencies are focusing much of their activity upon rural territory, but they vary greatly in size of staff and amount of resources at their disposal for the performance of their functions.

\section{Personnel for the Task}

Competent personnel is another essential factor in achieving satisfactory rural library service. As stated by a committee of the American Country Life Conference:

The librarian for a rural community should have had fundamental training in rural sociology and economics and a thorough acquaintance with the literature of rural life and problems. $^{3}$

Speaking of personnel, J. H. Kolb stated that "a rural library can be a library only when a person, carefully trained and highly sensitive, lives and works in the midst of rural life."

\section{Size of Service Units}

That the extension of library facilities to rural folk involved the creation of larger administrative units of service soon became evident to the pioneers in the movement. Melvil Dewey's "boxes of books" in the I89o's were followed by the Washington County "book wagon" in the early I900's

3 American Country Life Conference, 1944. Proceedings, p. 79 . and the establishment of county libraries. In addition to the county-type unit, of which several varieties exist, there are recommendations for multi-county and regional libraries, as well as federated groups of libraries in natural regions to achieve economy and adequacy.

As regards the optimum size of unit, J. H. Kolb in 1925 was of the opinion that a community must be large enough to support an annual budget of $\$ 4000$, the amount which he considered necessary for real library service. In 1934 Helen Gordon Stewart maintained that $\$ 15,000$ to $\$ 20,000$ should be minimum on which a community might operate library service. The PostWar Standards for Public Libraries in 1943 stated:

The minimum annual income for an efficient library unit in terms of ... essential services is approximately $\$ 25,000$, an amount which would normally provide service for a population of about $25,000 .^{5}$

After a study of the services rendered by 60 selected public libraries in the $5,000-$ 75,000 population group, Lowell Martin concluded "that the provisions of even modest essential elements of service were not obtained with any regularity until the 50,000 population or $\$ 40,000$ income group." Along with noting certain limitations to his conclusions, he adds:

If we believe that library service involves at least the elements suggested .... then the population minimum of 50,000 would need to be even larger when rural service is included. ${ }^{6}$

\section{Financial Support}

The financial support of rural library

4Cf. Long, Harriet C. County Library Service. Chicago, American Library Association, 1925; and Fair, Ethel M., ed. Countrywide Library Service. Chicago, American Library Association, 1934,

5 American Library Association. Committee on Postwar Planning. Post-War Standards for Public Libraries. Chicago, American Library Association, 1943, p. 46 .

p. University of Chicago. Graduate Library School. Op. cit. p. 46 . 
service raises controversial questions. It is clear that the rural areas themselves, with some exceptions, cannot raise enough money to operate adequate libraries if the tax base is confined to narrow limits. It is also a fact that 75 per cent of the number of public libraries in the United States have less than $\$ 4000$ annually on which to operate. $^{7}$ But what to do about it? At the time the Harrison-Thomas-Fletcher Bill (Federal Aid to Education) was being discussed in 1939, one noted American man of letters and metropolitan editor wrote that if people choose to live in out-of-theway places, that is their business, but they should not expect others to help them. In other words, every citizen should receive in public service only what he pays for in dollars and cents.

That is one point of view, and if carried to its logical conclusion, would do away with much service rendered by schools, post offices, roads, public health, and parks; and even municipal public libraries might be obliged, under such a policy, to check each would-be user to see whether he or his city ward had contributed an adequate share of the tax-dollar to the operating expenses of the institution.

Concern for the public interest and enlightened self-interest have tended, however, toward the policy of equalizing essential public services, even if it involves state aid and federal stimulating grants. In the case of libraries twenty-two states now are providing state aid for public libraries. In some states this financial assistance is nominal, such as New York's annual grant of $\$ 100$ to each registered library within the state; but in others it is sizable, such as the $\$ 300,000$ annual aid in Michigan; the $\$ 175,000$ in North Carolina; and the

U.S. Office of Education. Public Library Statistics 1938-39 by Ralph M. Dunbar and Edith M. Foster. Bulletin 1942, no. 4, p. 19-20. Data for 1945 now being compiled show some improvement in this item.
$\$ 200,000$ in Missouri, which joined the state aid ranks late in 1946 . Nine states are making state funds available for the aid of school libraries. In general, progress is being made, but it is slow and is meeting with occasional setbacks. Taken as a whole, the amounts are still woefully inadequate.

To hasten progress toward adequate library facilities for all, the A.L.A. Federal Relations Committee sponsored the "Public Library Service Demonstration Bill," which was introduced into the 79 th Congress. At first glance, this measure might appear to be merely a grab for federal money and of concern only to public librarians. Actually, it is of far wider significance, for the Senate committee's approving report concludes:

The proposals .... are designed to stimulate local and State action in providing an essential cultural and informational service.... The facilities provided under this bill are essential to the functioning of education in the United States. ${ }^{8}$

It would appear, therefore, that this bill which has been introduced as $\mathrm{S} .48$ in the 8oth Congress, has significant implications for college libraries. Any rise in educational facilities for the population as a whole surely concerns institutions of higher education. Likewise, any improvement in the educational and cultural background of students coming to college and any increase in library resources available in rural communities to students after leaving college, are of direct concern to college librarians.

\section{Assistance Needed from Colleges}

In solving this vast problem of developing rural library service, the cooperative assistance of many agencies, including college libraries, is required. Every college library is already overloaded with work and its

8 U.S. Senate. Committee on Education and Labor. 79th Congress, 2nd Session. Report No. 1575. 1946. 
prime obligation is to its students and faculty. Many college libraries, however, have been investing a small portion of their time in the cause of general library development and finding that it pays good dividends.

Perhaps one of the most common forms of assistance is interlibrary loans to the dwellers in rural communities. In the cooperating network, the college library can serve a useful purpose by making available from its specialized collections those items which the public library or the state library could not stock economically. Vanderbilt University has gone even somewhat further by organizing a circulating library for rural ministers, a service much needed by these leaders of country thought, culture, and morals.

Another form of assistance is the use of the radio to reach farm folk and villagers with news about books and to stimulate a desire for library facilities. Although only thirty-one institutions of higher education operate broadcasting stations, they have access to many commercial ones. On the part of the college library, this service has been sometimes indirect, such as supplying materials and facts for a broadcast or preparing recommended readings to accompany a program, but again it has been direct by actually reviewing books or reading substantial portions of them over the radio. A notable example of this latter service is found in the account of the WOI Radio Book Club:

This club was the logical outgrowth of an insistent demand from listeners to the various programs broadcast by the Iowa State College Library. These programs began in 1928. ... In 1928 the reading of books over the air was started. ${ }^{9}$

College librarians also can further the

\footnotetext{
9 Iowa State College. Extension Service. Booklist of the WOI Radio Book Club. Iowa State College, Ames, r933.
}

cause of rural libraries by seeing that libraries and the use of books are given due recognition in courses for training teachers, sociologists, extension workers, and others who may live and toil in farm and village communities. The county agent and the home demonstration workers, when fully awakened to the benefits of libraries, can become powerful advocates of such facilities.

Every bit of support given by college librarians to the strengthening of the official state library extension agency is work, in part at least, for the development of rural library service. This support may be in the form of action on the state library association's legislative committee, service on a state planning board, or assistance in activities in which the college with its subject specialists is equipped to serve.

College librarians can be helpful especially in research studies and institutes which deal with rural library problems. A recent example of this opportunity is found in the 1946 Michigan County Librarians Workshop in which the Michigan State Library, the Department of Sociology and Anthropology at Michigan State College, the Michigan Extension Service, the U.S. Department of Agriculture, and other agencies cooperated. The objective of the workshop was to see how the techniques of sociological research could assist in improving rural library service. Somewhat as an outgrowth of this project, the department of sociology and anthropology, with the cooperation of librarians, is undertaking a survey of reading habits and library needs in Lenawee County. ${ }^{10}$ There have been other instances of such activity. To mention only a few: the Rural Sociology Department of South Dakota State College issued in 1928 the results of its study, Equalizing Library Opportunity in South

10 From an unpublished paper by Edgar A. Schuler, Michigan State College, 1946. 
Dakota; the Iowa Agricultural Experiment Station in 1943 published Can Iowa Have Better Public Library Service? and James G. Hodgson of Colorado State College Library has completed a study having to do with reading in rural communities. College librarians participated in the Maryland study, which resulted in the 1944 report of the state planning commission, The Free Public Library in Maryland.

Back of any sound rural library program are many economic and social factors. For example, the authorities state that the family-type, owner-operated farm is the most basic and desirable method of holding the land. Certainly, this factor affects the foundation on which rural library service can be built and requires research. Since even the largest state library agencies seldom have sufficient staff and funds to undertake needed research before a program of action, college librarians and their colleagues in the political and social science fields have a promising opportunity to be helpful.

\section{Keeping the Perspective}

The development of adequate library resources in rural communities is not the only problem confronting librarians and educators, but it is one of the important ones. Intelligent action on social, economic, and technical questions requires access to unbiased, reliable sources of information by all citizens, urban and rural. Just as prosperity in one section of the nation helps other parts, so availability of rural library facilities, will benefit the thought and culture of the nation as a whole. 